\title{
Immunomodulation by the Female Sex Hormones
}

\author{
F.M. Menzies ${ }^{\S, 1}$ and F.L. Henriquez ${ }^{*}, 2$ \\ ${ }^{I}$ Strathclyde Institute of Pharmacy and Biomedical Sciences, University of Strathclyde, 27 Taylor Street, Glasgow G4 \\ ONR, UK \\ ${ }^{2}$ School of Science and Engineering, University of the West of Scotland, Paisley PA1 2BE, UK
}

\begin{abstract}
Pregnancy is a highly regulated process, requiring strict control of the immune system in order to prevent rejection of the semiallogenic foetus. One aspect of pregnancy immunology that has been of great interest is the influence of female sex and pregnancy associated hormones, such as progesterone and oestrogen, on cells of the immune system.

This review evaluates studies investigating the ability of these hormones to modulate the function of cells of both the innate and adaptive arms of the immune system and mechanisms by which immunity to infection can be altered due to increased levels of progesterone and oestrogen. Finally, the influence of pregnancy on the most common autoimmune diseases, on toxoplasmosis and on malaria is reviewed.
\end{abstract}

\section{INTRODUCTION}

Pregnancy is a complex process in which cells and molecules of the maternal immune system interact in such a way as to prevent the rejection of the semiallogenic foetus. Development and modulation of pregnancy is controlled by the presence and levels of various sex and pregnancy associated hormones, such as oestrogens and progesterones. In addition, the cytokine environment is important for a successful pregnancy, with studies showing a Th1 environment to be associated with abortion and a Th2 environment allowing the successful continuation of pregnancy [1].

The elevated levels of oestrogen and progesterone observed during pregnancy possess a number of modulatory functions on cells of the immune system, including macrophages, natural killer (NK) cells, dendritic cells (DCs), $\mathrm{T}$ cells and $\mathrm{B}$ cells. The endometrium is one of the most important organs during pregnancy [2] and presents an immunologically competent environment, with $30 \%$ of cells being of the immune system [3]. Within the uterus of nonpregnant women, NK cells, macrophages, $\mathrm{T}$ cells and $\mathrm{B}$ cells are abundant [2-4] and inhibit the implantation and the development of the embryo. However, during pregnancy, the activity of these cells against the foetus is specifically suppressed by oestrogen and progesterone, allowing successful embryo implantation [5-9].

*Address correspondence to this author at the School of Engineering and Science, University of the West of Scotland, 1 High Street, Paisley, PA1 2BE, Scotland, UK; Tel: 00441418483119 ;

E-mail: fiona.henriquez@uws.ac.uk

${ }^{\S}$ Current Address: Department of Reproductive and Maternal Medicine, Faculty of Medicine, University of Glasgow, Glasgow Royal Infirmary, 10 Alexandra Parade, Glasgow G31 2ER, UK

\section{EFFECT OF SEX HORMONES ON IMMUNE CELL FUNCTION}

\subsection{Innate Immunity}

\section{Macrophages}

Macrophages are known as Hofbauer cells in the human foetal chorionic villus of the placental unit [10]. Their distribution throughout uterine tissue depends on oestrogen and progesterone levels throughout the oestrous cycle [11]. They are present at the foetal-placental interface, in particular, around the spiral arteries, where they act to support the process of trophoblast invasion of the endometrium by phagocytosing apoptotic cells [12]. It has been suggested that macrophages within the decidua of the first trimester display characteristics of the alternatively activated phenotype as opposed to the classically activated phenotype [13]. However, in vitro studies have observed that the influence of $17 \beta$-oestradiol on macrophage function is varied, based on which cell line, species, or hormone concentration is used.

17ß-oestradiol administration to RAW 264.7 cells for 4 hours prior to LPS administration prevents the induction of the morphological changes typically seen with LPS alone [14]. In addition 17 $\beta$-oestradiol can modulate the ability of macrophages to produce various cytokines, for example, the downregulation of IL-1 $\beta$, IL- 6 and TNF- $\alpha$ by murine splenic macrophages $[15,16]$. Studies with LPS-treated rat peritoneal macrophages have shown that $17 \beta$-oestradiol influences TNF- $\alpha$ production by these in a concentration-dependent manner [17], whereas $17 \beta$-oestradiol has no effect on TNF- $\alpha$ production by cells of the murine J774A.1 line [18].

Macrophage function is also subject to modulation by progesterone. It has been shown in both rat and murine macrophages that progesterone reduces LPS and IFN- $\gamma$ stimulated nitrite production in a dose-dependent manner 
$[19,20]$. Jones et al. (2008) [21] further describe the ability of progesterone to down modulate nitrite production by murine bone marrow derived (BMD) macrophages through binding to the glucocorticoid receptor (GluR) rather than the progesterone receptor (PR). By comparison, IL-12 production by macrophages can be modulated by progesterone through either the glucocorticoid or progesterone receptor [21].

These experimental systems using macrophage cell lines and LPS can only be used to speculate the role that the female sex hormones have on macrophages found within the female reproductive tract or at the foetal-maternal interface. From these results, however, it can be assumed that oestrogens and progesterone will act to down modulate the inflammatory functions of these cells, as this would prove detrimental to the successful continuation of pregnancy.

\section{Dendritic Cells}

Within the uterus, DCs protect the host against pathogens without endangering the developing foetus by uptake of the apoptotic particles of the invading trophoblast [22]. CD83+ CD25+ DCs are present within the human decidua, as shown by both immunocytochemistry [23] and by flow cytometry [24]. Juretic et al. (2004) [25] have reviewed the role of DCs at the maternal-foetal interface and provide a model whereby stimulation of immature DCs in a Th2-bias environment (such as during pregnancy) will promote tolerogenic function, and stimulation in a Th1 bias environment will result in the maturation of DCs with a high capacity for antigen presentation. Since the Th2 environment associated with pregnancy is thought to be related to the high levels of progesterone and oestrogen present within the female reproductive tract, a great deal of focus has recently centred on the influence of these hormones on DCs.

Initial studies on the immunomodulation of DCs by oestrogens were carried out through use of toremifine and tamoxifen [26, 27]. These antioestrogens inhibit the differentiation of monocytes into DCs, suggesting that oestrogens are important in the development of DCs from their precursors. This was confirmed in studies by Paharkova-Vatchkova et al. (2004) [28], who showed that $17 \beta$-oestradiol promotes the differentiation of DCs from murine bone marrow precursors, rather than increasing the proliferation of existing DCs. Furthermore, in recent studies it is demonstrated that DC differentiation is regulated by the oestrogen receptor- $\alpha$ (ER- $\alpha)$ [29].

$17 \beta$-oestradiol has the ability to modulate cytokine production by DCs. However, there is a lack of consistency between studies, as it appears to be biphasic in its functions, dependent upon which concentration is used [30-33]. For example, production of the proinflammatory cytokine IL-6 by immature peripheral blood mononuclear cell (PBMC)derived human DCs is only affected by $17 \beta$-oestradiol at concentrations above $1 \mathrm{mg} / \mathrm{ml}$ where a dose-dependent increase in IL-6 production is observed [34].

IL-10 is an anti-inflammatory cytokine and although some studies have shown that $17 \beta$-oestradiol has no effect on IL-10 production by immature PMBC-derived DCs [34], others have found that $17 \beta$-oestradiol can cause a significant increase in IL-10 production in human PBMC-derived DCs up to a concentration of $10 \mathrm{ng} / \mathrm{ml}$ [31], a level which corresponds to pregnancy.

The ability of $17 \beta$-oestradiol to modulate IL-12 production by immature and mature DCs is below the range of detection $[31,34]$. Similarly, levels of the proinflammatory cytokine TNF- $\alpha$, either released by immature DCs or found intracellularly, are unaffected by $17 \beta$-oestradiol [31, 33, 34]. The effect of progesterone on cytokine production reveals that in murine BMD-DCs, IL-6 and IL-12 production is unaffected, however, IL-10 and TNF- $\alpha$ is increased [31]. Since TNF- $\alpha$ is a Th1 proinflammatory cytokine, it is generally regarded as dangerous to the developing foetus. However, in vivo, progesterone will not be found in isolation and therefore if TNF- $\alpha$ levels are looked at in response to both progesterone and oestrogen at a range of concentrations, then it can be seen that TNF- $\alpha$ remains at basal levels [31].

\section{Natural Killer Cells}

Studies in murine models have found that uterine natural killer (uNK) cells are crucial for successful implantation and are found on the mesometrial side of the pregnant uterus [35]. During the first trimester of pregnancy in humans, uNK cells reach peak numbers, making up $70 \%$ of all lymphocytes present, however by full-term pregnancy, no uNK cells are detectable [36]. NK cells are a well-known source of IFN $\gamma$ and studies in IFN- $\gamma^{-/}$mice and RAG- $2^{-1 /} \gamma_{c}^{-/-}$mice demonstrate that IFN- $\gamma$ production by murine uNK cells is important for vascular remodelling, maintenance of the deciduas within the second trimester and regulation of the uNK cell population [37-40]. Decidual NK (dNK) cells have the potential to produce not only Th1-associated cytokines (NK1), but also Th2-associated cytokines (NK2) given an appropriate stimulus, and immunoregulatory cytokines such as TGF- $\beta$ (NK3) and IL-10 (Nkr1) [41], which would contribute to the provision of a suitable environment for successful pregnancy. Decreased numbers of Nkr1 and NK3 cells have been associated with the phenomenon of spontaneous abortion [41]. Furthermore, in humans, the non-classical MHC class I molecule HLA-G is expressed in the placenta and can inhibit trafficking of maternal NK cells across the placenta [42], thereby protecting the foetal cells from rejection [39].

NK cell activity differs throughout the human menstrual cycle, with higher levels of activity observed in those women in the follicular phase of the cycle than the luteal phase [43]. This suggests that NK cells are influenced by oestrogen and progesterone. As illustrated in Fig. (1), NK cell activity can also be modulated by the release of Progesterone-Induced Blocking Factor (PIBF), a 34-kDa protein produced by decidual lymphocytes upon exposure to progesterone. Despite being necessary during pregnancy at the foetal-maternal interface, uNK cells still possess high concentrations of perforin, a molecule that mediates NK cell cytotoxicity. PIBF has been found to downmodulate the cytotoxic activity of NK cells [4446] through inhibition of arachidonic acid release from lymphocytes, which subsequently reduces prostaglandin production and IL-12 release [47]. IL-12, in conjunction with IFN- $\gamma$, normally promotes NK cell activity. In this setting, lowered NK cell activity contributes to the successful continuation of pregnancy. 


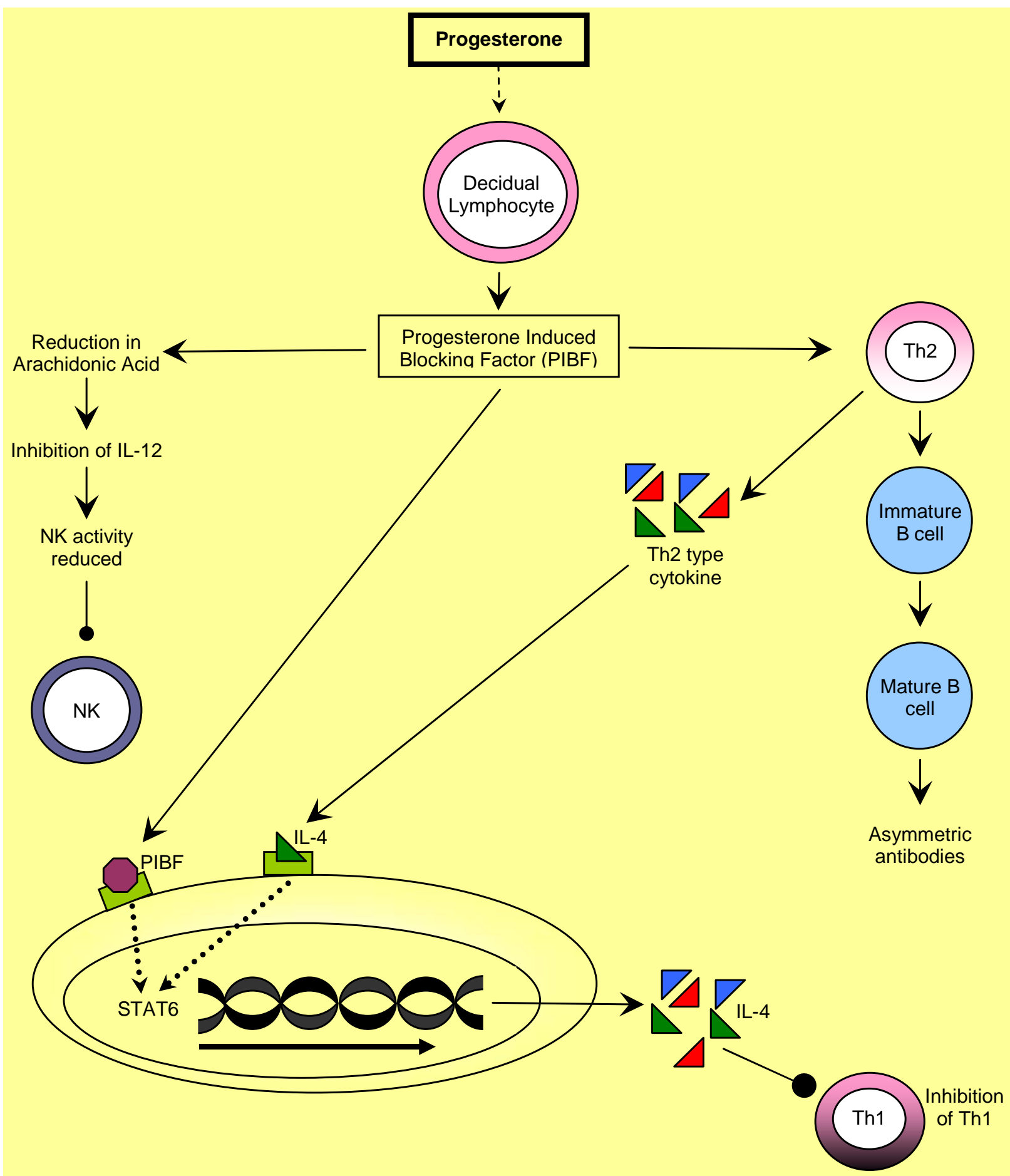

Fig. (1). Examples of effects of Progesterone Induced Blocking Factor (PIBF) on cells of the immune system. Progesterone induces production of PIBF from deciudal lymphocytes, which can act to potentiate the Th2 environment associated with pregnancy. PIBF reduces NK cell cytotoxicity, stimulates production of asymmetric antibodies, and increases IL-4 production by a STAT6 dependent mechanism. In doing so, Th1 responses are inhibited [44-46].

\subsection{T Cells}

It has been observed that during pregnancy there is a general substantial improvement in the symptoms of Th1associated autoimmune diseases such as multiple sclerosis, rheumatoid arthritis (RA) and thyroiditis. For example, only patients with rheumatoid arthritis negative for autoantibodies improve during pregnancy [48]. This has been widely attributed to a bias towards a Th2 cytokine environment [49].

The cytokine profile is important for the maintenance of pregnancy. Murine studies have found that IFN- $\gamma$ is only detectable during the first and second trimesters of successful pregnancy, whereas the Th2 cytokines IL-4, IL-5 
and IL-10 are constitutively secreted by the foetal-placental unit until term [50]. Makhseed et al. (2001) [1] describe a strong Th1 bias in abortion-prone women and recurrent aborters, in comparison with women who have normal pregnancies.

Examination of the effects of pregnancy hormones on $\mathrm{T}$ cell populations have identified potential explanations to the shift towards to Th2 environment. In vitro studies illustrate that progesterone can influence the functional differentiation into Th1 and Th2 subsets by enhancing IL-4 and IL-10 producing $\mathrm{T}$ cells and reducing the ability of $\mathrm{T}$ cells to secrete IFN- $\gamma[51]$.

Another potential mechanism for the modulation of Th1/Th2 balance is via the action of PIBF (Fig. 1). This molecule contributes to the reduction in cell-mediated responses that could be detrimental during pregnancy. In addition to the prevention of NK cell activity [44-46], PIBF has been shown to skew the immune environment to a Th2 phenotype through increasing the production of IL-3, IL-4 and IL-10 from both CD4+ and CD8+ T cells in vitro [52] and in vivo [53]. Kozma et al. (2006) [54] have suggested the existence of a novel IL-4R, comprised of the IL- $4 \mathrm{R} \alpha$ chain in association with a GPI-anchored PIBF receptor, which subsequently activates STAT6 upon binding of PIBF. This mechanism occurs through protein kinase $\mathrm{C}$ (PKC) phosphorylation without any adjustments in intracellular $\mathrm{Ca}^{2+}$ levels [55].

As reviewed by Pernis (2007) [56], oestrogens can also modulate various aspects of CD4+ T helper cell development and function. Oestrogens can influence the Th1/Th2 balance by depressing Th1 and favouring Th2 responses [30]. Consequently, females exhibit higher Th2 immunity than males, and therefore produce higher levels of IL-4, IL-5, IL6 and IL-10 [57]. Contrary to this, a study by Fox et al. (1991) [58] has shown that 17 $\beta$-oestradiol directly stimulates the IFN- $\gamma$ promoter, which would suggest a role for oestrogens in the development of a Th1 response. Furthermore, studies show that $17 \beta$-oestradiol has the capability to induce the development of IFN- $\gamma$ producing cells [59]. The contradictory Th1 and Th2 inducing ability of the oestrogens could be due to the concentration present, as suggested by Beagley and Gockel (2003) [30]; as low concentrations may favour IFN- $\gamma$ production and higher concentrations may favour IL-10 production by the same cells. Therefore $17 \beta$-oestradiol is biphasic in its actions, with low doses facilitating induction of immune responses and higher doses, such as those present during pregnancy, suppressing immune activation.

As well as acting to influence mature $\mathrm{T}$ cells through alteration of cytokine production, both progesterone and oestrogen influence $\mathrm{T}$ cell development. Moreover, progesterone can inhibit $\mathrm{T}$ cell lymphopoiesis at the pre- $\mathrm{T}$ cell (CD3- CD44+ CD25+) stage in a progesterone-receptor (PR) dependent mechanism during pregnancy, by a process also described as necessary for normal fertility [60]. In contrast, during a subsequent study by Rijhsinghani et al. (1996) [61], it was found that progesterone had no ability to block $\mathrm{T}$ cell development, with oestrogen instead having an effect on $\mathrm{T}$ cell development. As well as reducing thymus size and cellularity, oestrogen reduced the numbers of both the CD4+ and CD8+ T cell populations [61].
In addition to the alteration of Th1 and Th2 cell behaviour in the presence of female sex hormones, tolerance of the semiallogenic foetus is also achieved through the actions of the $\mathrm{CD} 4+\mathrm{CD} 25+$ regulatory $\mathrm{T}$ cells (Tregs) population. These cells have been implicated in the control of autoimmune diseases and in doing so can act to potentiate self-tolerance. This concept has been applied in many studies, both human and murine, to understand the role of these cells in maintenance of maternal tolerance of the foetus [reviewed 62, 63]. Human Tregs have been classified into $\mathrm{CD} 4+\mathrm{CD} 25^{\text {low }}$ and $\mathrm{CD} 4+\mathrm{CD} 25^{\text {high }}$ populations, with the former having no immunoregulatory functions and the latter having a strong potential for regulation [62]. CD4+CD25 $5^{\text {high }}$ Tregs constitute $2-6 \%$ of CD4 $+\mathrm{T}$ cells in humans [62]. In mice, Tregs are simply described as $\mathrm{CD} 4+\mathrm{CD} 25+$, and constitute approximately $10 \%$ of $\mathrm{CD} 4+\mathrm{T}$ cells. The existence and role of these cells in the maintenance of pregnancy has been elucidated by the identification of the essential transcription factor Foxp3 as a marker for the cell type $[64,65]$. Pregnancy is associated with an increase in the number of Tregs in the blood, most prevalent during the second trimester [66] and in the decidua [67]. Aluvihure et al. (2004) [68] showed that the maternal population of CD4+CD25+ Tregs in mice is systemically expanded, rather than in the thymus, during pregnancy and this is independent of alloantigen. A subsequent study has since shown data to support that the expansion of CD4+CD25+ Tregs is driven by foetal alloantigen [69]. The conflicts in these results are possibly due to differences in the time periods examined.

One method by which Tregs are thought to mediate maternal tolerance of the foetus is through induction of the enzyme indoleamine 2,3-dioxygenase (IDO), expressed by a variety of cells including macrophages [70] and DCs [71]. This enzyme acts to deplete essential amino acid tryptophan and in doing so, prevents $\mathrm{T}$ cell attack of the developing foetus [72, reviewed by 73,74$]$. IDO expression is upregulated in DCs and both peripheral and blood monocytes through Treg expression of CTLA-4 [75] possibly after exposure to foetal antigen.

The direct effects of the female sex and pregnancyassociated hormones on Tregs is presently an understudied area. Most of the work carried out in this area has focused on the ability of oestrogen to potentiate the ability of Tregs to suppress immune function. Interestingly, it has been found that oestrogen increases the proportion of CD4 $+\mathrm{T}$ cells that are $\mathrm{CD} 25+$ as well as increases Foxp3 expression and enhances Treg suppression [76-78]. It remains to be seen what the effect of progesterone, in the presence or absence of oestrogen, has on the expansion and function of the Treg population and what signalling mechanisms are involved.

\subsection{B Cells and Antibodies}

During pregnancy, humoral immunity predominates with an overall increase in total antibody production, however generation of new B cells is reduced. It has been shown that oestrogen causes a selective reduction in pre-B cells and IL7-responsive cells in the bone marrow [79], with subsequent studies demonstrating that oestrogen influences B lymphopoiesis by altering early, critical events [80]. It has been strongly suggested that the down regulation of $\mathrm{B}$ cell lymphopoiesis is due to the expression of $\mathrm{Bcl} 2$ [81]. This 
antiapoptotic molecule is regulated by progesterone, which interacts directly with its promoter [82].

Asymmetric antibodies are IgG molecules that possess a mannose-rich oligosaccharide in one arm of the Fab region [83]. The altered structure of these molecules therefore renders them ineffective at activating the effector functions typically associated with antibodies such as opsonisation for phagocytosis and complement fixation. It was first suggested by Malan Borel et al. (1991) [84] that these molecules function to protect the foetus by acting as blocking antibodies. It has since been recognised that higher levels of asymmetric antibodies exist in healthy pregnant women than in recurrent aborters [85]. This action has been attributed to the ability of progesterone to induce PIBF (Fig. 1). Asymmetric antibodes play a protective role during pregnancy by inactivating the effector mechanisms, which could attack the semiallogenic foetus [86, 87].

\section{SIGNALLING OF THE FEMALE SEX HORMONES}

In order for oestrogen and progesterone to exert their immunomodulatory functions, they must first bind to receptors. The receptors involved and signalling pathways induced upon hormone release is complex and not yet fully understood.

\subsection{Oestrogen Receptors}

Oestrogen receptors exist in two isoforms, ER- $\alpha$ and ER$\beta$, which are the products of two genes on different chromosomes. Oestrogen is able to function via genomic or non-genomic mechanisms $[88,89]$. The genomic mechanism refers to the binding of oestrogen to nuclear (intracellular) receptors, which are ligand dependent transcription factors capable of regulating gene expression in a number of ways including direct DNA binding of homodimers / heterodimers of ER- $\alpha$ and ER- $\beta$, or by binding to other transcription factors [90]. ERs modulate gene expression through transcription activation functions, AF-1 and AF-2, which bind coactivators or corepressors. As well as binding nuclear receptors, oestrogen can rapidly modulate cells by binding to membrane ERs [91], although oestrogen itself does not increase the expression of membrane ER- $\alpha$ [92].

The presence of ERs on immune cells has been of great interest in recent times. By carrying out quantitative RTPCR, Phiel et al. (2005) [93] have shown that CD4+ T cells express a greater level of ER- $\alpha$ mRNA than ER- $\beta$ mRNA, with CD8+ T cells expressing a similar, but low, level of mRNA for both ER- $\alpha$ and ER- $\beta$. In addition it was shown that B cells express a higher level of ER- $\beta$ mRNA than ER- $\alpha$ mRNA. At the protein level, it was found that both CD4+ and CD8+ T cells possess $17 \beta$-oestradiol binding sites [94], B cells express nuclear ERs but not membrane ERs [95] and macrophages also express nuclear ERs [96, 97].

\subsection{Progesterone Receptors}

Progesterone has the ability to exert its functions through both the Progesterone receptor (PR) and the Glucocorticoid Receptor (GluR) [98]. The PR is an intracellular receptor that is a member of the nuclear receptor superfamily [99, 100] and exists in two distinct isoforms, PR-A and PR-B, both of which are transcribed from a single gene, but regulated via distinct promoters [101-103]. The PR can be expressed constitutively, for example, in mice the $\mathrm{PR}$ is found in the smooth muscle cells of the uterus, uterine blood vessels and urinary bladder, to name a few [104]. However, PR expression can be upregulated by oestrogen, despite neither isoforms containing an oestrogen response element (ERE). Interestingly, Flötotto et al. (2004) [105] found that PR-B expression is stimulated by only ER- $\alpha$ by an AF-1 dependent mechanism.

The PR can also mediate its biologic functions through either genomic or non-genomic mechanisms [106]. Classical genomic signalling involves the binding of progesterone to the receptor, inducing a conformational change in its structure, leading to the separation of a multi-protein chaperone complex. In doing so, receptors can form homodimers which are able to bind the progesterone response elements (PREs) within the promoter regions of target genes to modulate gene expression [100]. Recently, a great deal of effort has been made to understand the nongenomic signalling mechanisms that mediate the rapid, membrane-initiated effects of progesterone [107] due to the potential for therapeutic modulation.

The presence of a classical progesterone receptor on immune cells is an area of much controversy. Immunohistological studies that neither PRs nor ERs were present on lymphocytes, macrophages or uterine NK cells [108]. In contrast, subsequent studies have demonstrated the existence of PRs and ERs in macrophages and NK cells by quantitative RT-PCR and immunohistochemistry [97, 109]. In addition, membrane PRs are also present in human $\mathrm{T}$ cells [110].

\section{PREGNANCY AND AUTOIMMUNE DISEASE}

Generally during pregnancy there is a substantial improvement in the symptoms.

of Th1-associated autoimmune disease. However, some autoimmuneconditions can cause risks and complications for both the pregnant woman and the foetus [111]. For example, in Graves' disease anti-thyroid autoantibodies can result in miscarriages, premature births and intrauterine growth retardation for the foetus. The expectant mother can develop high blood pressure and heart complications [111]. Hashimoto's thyroiditis is characterised by $T$ cell autoreactivity against thyroid antigens, thus causing hypothyroidism and a decrease in the IQ of children born to mothers suffering from the disease [112].

Hashimoto's thyroiditis fluctuates during pregnancy. The autoimmune component ameliorates during the second half of gestation but is aggravated post-partum [113]. This may be due to the shift in T cell responses. In marked contrast, in the case of type 1 diabetes (IDDM) sufferers, symptoms are not alleviated during pregnancy and patients must be carefully monitored as IDDM can be induced by both Th1 and Th2 events [114]. In clinical studies of patients affected by inflammatory bowel disease, the outcome of pregnancy is normal, although there is an increased risk of premature delivery or low birth weight [115]. Stillbirth, congenital abnormalities and preterm labour are often associated with inflammatory activity at conception, whereas absence of inflammation leads to a normal outcome [116, 117]. As a result patients are advised to conceive during remission. However, Crohn's disease is exacerbated in the last trimester 
and post-partum, and this is thought to be due to the decrease of endogenous corticosteroids after delivery [118]. In other inflammatory bowel conditions, such as ulcerative colitis, pregnancy appears to increase disease activity during the first trimester [119]. Usually, ulcerative colitis is also associated with low birth weight and preterm labour but there is evidence to illustrate that infants born to mothers with this condition may experience neurological sequelae [120].

In Systemic Lupus Erythematosus (SLE) an association between activedisease at conception and danger to the foetus has been reported [121]. There has been much debate as to whether SLE is ameliorated or exacerbated during pregnancy, with studies providing evidence for both cases [122]. However, if flares of SLE occur, they are no more severe during pregnancy than before [123]. Recent studies highlight the increased danger to both mother and foetus of lupus nephritis at the time of conception. This is due to increased episodes of hypertension and a higher risk of preeclampsia [122]. In addition, the transplacental passage of antiphospholipid antibodies can result in neonatal lupus syndromes, with ensuing $t$ higher risk of congenital heart problems and transient cutaneous lupus for the foetus [124]. The exacerbation of SLE is attributed to the presence of oestrogens, which favour humoral immunity, and prolactin, which has an effect on the $\mathrm{T}$ and $\mathrm{B}$ lymphocyte population $[125,126]$. Since pregnancy in general results in a suppression of cell-mediated responses, humoral immunity is preserved and thus the production of autoantibodies is not affected. The symptoms of Rheumatoid Arthritis (RA) are generally alleviated during pregnancy. RA is characterised by a severe inflammation and destruction of the joints and by extraarticular manifestations, including vasculitis. These symptoms improve dramatically during early pregnancy and the patient can go into complete remission towards the end of gestation. Such amelioration is likely to be caused multiple factors including the major shift from a Th1 to a Th2/Treg environment, the presence of $\alpha-2$ pregnancyassociated globulin (PAG) [122] and increase in sex hormones and serum cortisol, which suppress proinflammatory cytokines and favour IL-10 through the action of PIBF [53]. Exacerbation of RA can be seen in these patients 3-4 months postpartum, and prolactin may have a role in these flares $[127,128]$.

\section{PREGNANCY AND INFECTION}

During pregnancy many diseases are more severe and danger to the foetus and transplacental transmission may occur. Pregnant females in general are more susceptible to infection than non-pregnant females. Increase disease susceptibility and severity during pregnancy has been documented for a variety of diseases, including bacterial (Leprosy, Listeriosis) [129-131], viral (HIV, Influenza, Measles) [132-134] and parasitic (Malaria, Toxoplasmosis) [135, 136]. It is the change in immune function during pregnancy that alters susceptibility and severity to these infections. For example, some studies have suggested a greater susceptibility to HIV in the presence of elevated

Table 1. Immunological Response to Parasite Infections During Pregnancy

\begin{tabular}{|c|c|c|c|c|}
\hline Parasite & Host & Response to Infection & Effect of Infection During Pregnancy & References \\
\hline Leishmania major & C57BL/6 mouse & $\begin{array}{l}\text { Th1 response: } \\
\text { ヤ IFN- } \gamma \& \text { IL-12 }\end{array}$ & $\begin{array}{c}\text { If there are } \uparrow \text { levels of IFN- } \gamma \text { induced by parasite this } \\
\text { leads to implantation failure and resorption } \\
\qquad \begin{array}{l}\text { IFN } \gamma, \uparrow \text { IL-4, IL-5, IL-10, IgG1 }\end{array}\end{array}$ & $\begin{array}{l}{[154]} \\
{[155]}\end{array}$ \\
\hline \multirow[t]{2}{*}{ Neospora caninum } & $\mathrm{BALB} / \mathrm{c}$ mouse & $\begin{array}{l}\text { Th1 response: } \\
\text { 个 IFN } \gamma, \text { IL-12 }\end{array}$ & ^ IL-4, $\downarrow$ IFN $\gamma$, IL-12, TNF $\alpha$ & {$[156-158]$} \\
\hline & Cattle & $\begin{array}{c}\text { Th1 response: } \\
\boldsymbol{\uparrow} \text { IFN-g production by NK cells }\end{array}$ & $\begin{array}{l}\text { Th1 response to control parasite multiplication leads to } \\
\text { destruction of placental tissues. } \\
\text { Infiltration of CD4+ T cells, } \gamma \delta \text { T cells \& NK cells } \\
\uparrow \text { IL-1 } \beta \text {, IL-8, TNF } \alpha \\
\downarrow \text { IL-6, TGF } \beta \text { by placental macrophages leading to } \\
\text { inflammatory response in placenta }\end{array}$ & {$[159,160]$} \\
\hline $\begin{array}{l}\text { Plasmodium } \\
\text { falciparum }\end{array}$ & Human & 个 TNF $\alpha$, IFN $\gamma$ & Infiltration of immune cells & {$[161,162]$} \\
\hline \multirow[t]{2}{*}{ Toxocara canis } & Dog & $\begin{array}{l}\text { 个 CD4+ \& CD8+ T cells, } \uparrow \text { in } \\
\text { IL-4, IL-5 \& IgE production }\end{array}$ & $\begin{array}{l}\uparrow \text { susceptibility: } \uparrow \text { in IL-10 production during } \\
\text { pregnancy, decrease in IFN- } \gamma \text { production }\end{array}$ & {$[163]$} \\
\hline & $\begin{array}{l}\text { C57BL6/J } \\
\text { mouse }\end{array}$ & $\begin{array}{l}\text { Th2 response: eosinophilia, i个 in } \\
\text { IgE production, } \uparrow \text { in CD4+ and } \\
\text { CD8+ T cells }\end{array}$ & $\begin{array}{c}\boldsymbol{\uparrow} \text { susceptibility: } \boldsymbol{\uparrow} \text { in CD4+ T cells in early infection, } \boldsymbol{} \\
\text { in CD8+ T cells in late infection }\end{array}$ & {$[164]$} \\
\hline \multirow[t]{2}{*}{ Trypanosoma cruzi } & Human & $\uparrow \mathrm{IFN}-\gamma$ & $\begin{array}{c}\boldsymbol{\uparrow} \text { susceptibility: } \boldsymbol{\downarrow} \text { in IFN- } \gamma \text { leading to increased } \\
\text { parasitaemia } \\
\boldsymbol{\downarrow} \text { in activation of CD4+ T cells and monocytes }\end{array}$ & {$[165]$} \\
\hline & $\mathrm{BALB} / \mathrm{c}$ mouse & $\uparrow$ IFN- $\gamma$ and TNF- $\alpha$ & $\begin{array}{l}\text { 个 susceptibility: Parasite invasion of deciduas resulting } \\
\text { in foetal growth retardation and death }\end{array}$ & {$[166]$} \\
\hline Toxoplasma gondii & $\mathrm{BALB} / \mathrm{c}$ & $\begin{array}{c}\uparrow \mathrm{IFN} \gamma, \mathrm{IL}-12, \mathrm{CD} 8+\mathrm{T} \text { cell } \\
\text { activity }\end{array}$ & $\begin{array}{c}\downarrow \text { CD4+ T cells, CD8+ T cells } \\
\text { Congenital transmission to foetus as parasite } \\
\text { multiplication is not controlled }\end{array}$ & {$[167]$} \\
\hline
\end{tabular}




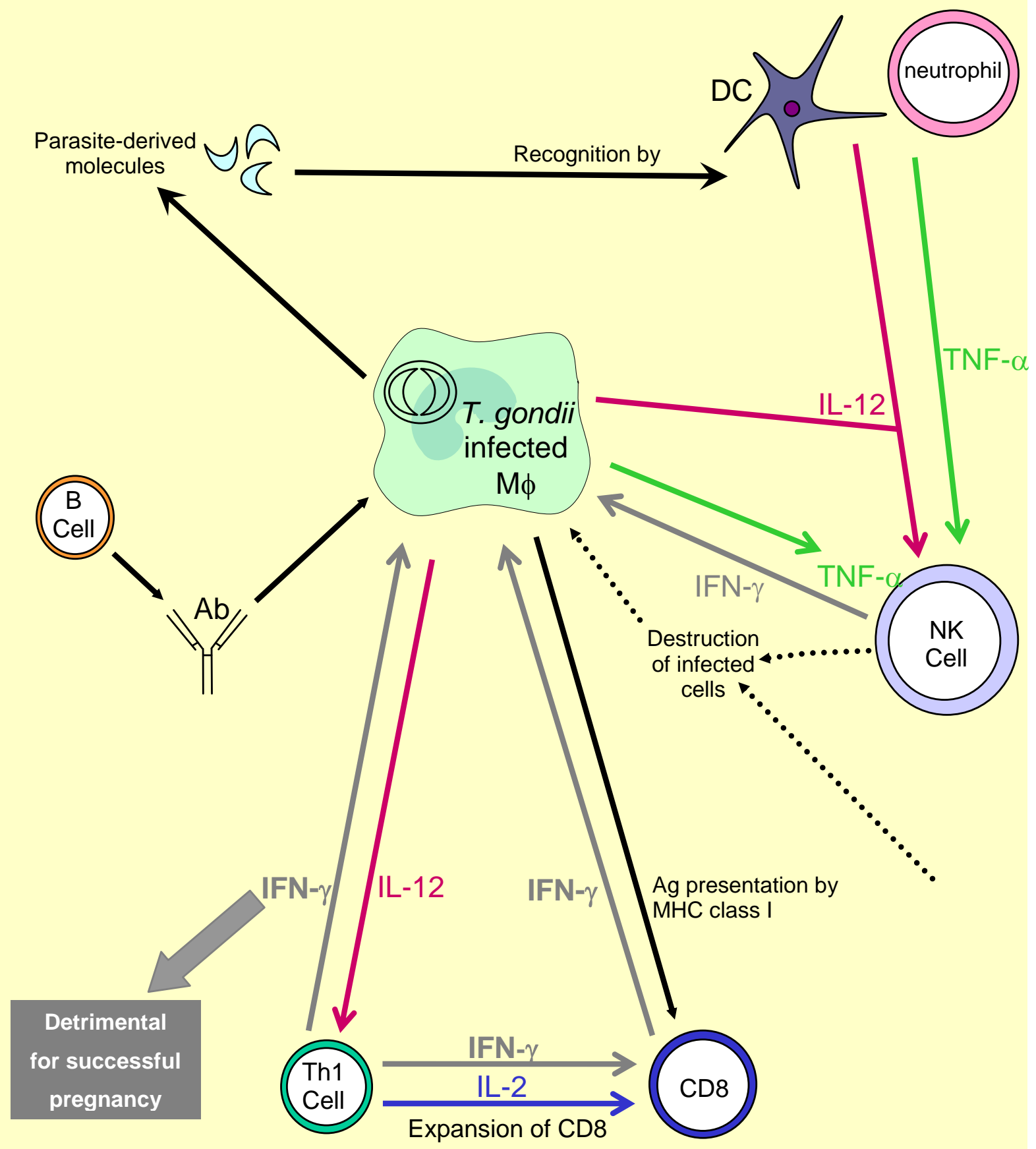

Fig. (2). Summary of protective type 1 immune response elicited by $T$. gondii infection. Upon infection of a host cell, such as the macrophage, IL-12 is released which induces the expansion of CD4+ Th1 cells as well as the effector mechanisms of NK cells. IFN- $\gamma$ release from Th1 cells, CD8+ T cells, NK cells further promotes the effector mechanisms of macrophages such as tryptophan degradation and NO release. Humoral immunity is involved by release of antibodies which can induce complement or opsonise tachyzoites to prevent further parasite dissemination. Release of parasite derived molecules such as cyclophilin, HSP70 and profilin induce the release of cytokines including IL-12 and TNF- $\alpha$ from DCs and neutrophils. [Ab=antibody, Ag = antigen].

concentrations of progesterone $[137,138]$. An increase in progesterone levels can decrease vaginal epithelium thickness [139] and sex steroids can increase the expression of co-receptors CXCR4, CD4 and CCR5 important in viral invasion of the host cells expression [140]. In addition, severity of disease during pregnancy is also associated with physiological changes, such as increased heart rate, stroke volume, oxygen consumption and lung capacity [141]. Many studies, focusing on infections during pregnancy, have utilised parasitic model infections to understand the alteration of immune function during pregnancy and the danger to the foetus.

\subsection{Parasites and Pregnancy}

A fine balance exists between host and parasite to ensure survival of both. The cytokine environment is often key in this process, and pregnancy can often lead to changes in the way this balance is maintained. Pregnancy is generally 
regarded as a Th2 phenomenon, due to the influence that the female sex hormones have on immune cells. Alteration of the cytokine environment as the immune system responds to the presence of infection often leads to detrimental consequences for both mother and foetus. On the other hand, adjustments of the cytokine profile induced by pregnancy can change the ability of an individual to control a parasite infection. A number of studies have been carried out to consider the effect that parasites have on the mother and foetus during pregnancy and also to consider the effect that pregnancy has on the ability to control parasite numbers, some of which have been summarised in Table $\mathbf{1}$.

One parasite, which has been extensively studied for its effects on immunity during pregnancy, is the protozoan Toxoplasma gondii. Female mice are more susceptible than males to T. gondii infection [142], and this has been attributed to the effect of the female sex hormones [15]. In addition, this parasite can be congenitally transmitted if the mother is infected for the first time during pregnancy, with the trimester at which infection occurs determining whether the foetus is aborted or survives to term, but possessing foetal abnormalities [143]. As summarised in Fig. (2), infection with $T$. gondii is characterised by induction of a Th1 type immune response, with production of IFN- $\gamma$ and CD8+ T cell activity being crucial for control of the parasite [144-147]. IFN- $\gamma$ production, as part of a Th1 immune response, is associated with abortion and so the immune response to the parasite can have detrimental consequences for the foetus. On the other hand, the Th2 environment conducive to pregnancy favours the multiplication and maintenance of the parasite. Moreover, T. gondii-infected IFN- $\gamma$ deficient pregnant mice are less likely to abort the foetus, but exhibit high numbers of parasite within the uterus and placenta [148].

Malaria infections have presented the world with a great epidemiological problem in recent times. Four species (Plasmodium falciparum, P. malariae, $P$. ovale and $P$. vivax) cause malaria in humans, with $P$. falciparum infection being especially problematic during pregnancy. The prevalence of maternal malaria infection in Africa is approximated at $25 \%$ [149] and congenital transmission to the foetus estimated at $33 \%$ [136], therefore understanding the immune response to malaria infection is important with regard to transmission of infection and possible chemotherapeutics during pregnancy. As with $T$. gondii infection, malaria induces a strong Th1 type response in the mother, resulting in implantation failure and abortion of the foetus [150]. Much of the pathology is due to the ability of the parasite to reside within red blood cells in the placenta, mediated by binding of the parasite to chondriotin sulphate A and hyalaronic acid receptors on placental endothelial cells [151].

A recent study has considered the effects of the female sex hormones on P. chabaudi infection in C57BL/6 mice and found that administration of oestrogen alone or in combination with progesterone reduced infection-induced weight loss without actually effecting levels of parasitaemia [152]. This data suggested that oestrogens exhibit a protective effect for the mother by increasing levels of IFN- $\gamma$ and IL-10, however this study did not consider pregnancy outcomes. The stress hormone cortisol has been found to be increased in $P$. falciparum-infected pregnant women compared with non-infected pregnant women [153]. At the time of delivery, cortisol concentrations were approximately 2.5 times higher than in non-pregnant women. It could be suggested that the parasite induces additional cortisol production as a means of dampening immune cell function.

\section{CONCLUDING REMARKS}

The female sex and pregnancy associated hormones have a wide range of effects on the cells of the immune system to allow the successful continuation of pregnancy by preventing rejection of the foetus. The modulation of the action of these cells often has implications for other aspects of immunity, such as altering the ability to deal with infection or autoimmune diseases. Much remains to be learned about the way in which cells and molecules can interact and be influenced.

\section{REFERENCES}

[1] Makhseed M, Raghupathy R, Azizieh F, Omu A, Al-Shamali E, Ashkanan L. Th1 and Th2 cytokine profiles in recurrent aborters with successful pregnancy and with subsequent abortions. Hum Reprod 2001; 16: 2219-26.

[2] Loke YW, King A. Immunological aspects of human implantation. J Reprod Fertil Suppl 2000; 55: 83-90.

[3] Critchley HO, Kelly RW, Brenner RM, Baird DT. The endocrinology of menstruation--a role for the immune system. Clin Endocrinol 2001; 55: 701-10.

[4] Chantakru S, Wang WC, van den Heuvel M, et al. Coordinate regulation of lymphocyte-endothelial interactions by pregnancyassociated hormones. J Immunol 2003; 171: 4011-9.

[5] Thongngarm T, Jenkins JK, Ndebele K, McMurray RW. Oestrogen and progesterone modulate monocyte cell cycle progression and apoptosis. Am J Reprod Immunol 2003; 49: 129-38.

[6] Chaouat G, Ledee-Bataille N, Zourbas S, et al. Cytokines, implantation and early abortion: re-examining the Th1/Th2 paradigm leads to question the single pathway, single therapy concept. Am J Reprod Immunol 2003; 50: 177-86.

[7] Galan A, O'Connor JE, Valbuena D, et al. The human blastocyst regulates endometrial epithelial apoptosis in embryonic adhesion. Biol Reprod 2001; 64: 1283.

[8] Salamonsen LA, Nie G, Dimitriadis E, Robb L, Findlay JK. Genes involved in implantation. Reprod Fertil Dev 2001; 13: 41-9.

[9] Ma WG, Song H, Das SK, Paria BC, Dey SK. Oestrogen is a critical determinant that specifies the duration of the window of uterine receptivity for implantation. Proc Natl Acad Sci USA 2003; 100: 2963-8.

[10] Castellucci M, Kaufmann P. A three-dimensional study of the normal human placental villus core: II: stromal architecture. Placenta 1982; 3: 269-85.

[11] De W, Wood GW. Influence of oestrogen and progesterone on macrophage distribution in the mouse uterus. J Endocrinol 1990; 126: 417-24.

[12] Mor G, Abrahams VM. Potential role of macrophages as immunoregulators of pregnancy. Reprod Biol Endocrinol 2003; 1: 119-26.

[13] Cupurdija K, Azzola D, Hainz U, et al. Macrophages of human first trimester deciduas express markers associated to alternative activation. Am J Reprod Immunol 2004; 51: 117-22.

[14] Vegeto E, Ghisletti S, Meda C, Etteri S, Belcredito S, Maggi A. Regulation of the lipopolysaccharide signal transduction pathway by $17 \beta$-oestradiol in macrophage cells. J Steroid Biochem Mol Biol 2004; 91: 59-66.

[15] Roberts CW, Walker W, Alexander J. Sex-associated hormones and immunity to protozoan parasites. Clin Microbiol Rev 2001; 14 : 476-88.

[16] Deshpande R, Khalili H, Pergolizzi RG, Micael SD, Chang MD. Estradiol down-regulates LPS-induced cytokine production and NF-kB activation in murine macrophages. Am J Reprod Immunol 1997; 38: 46-54.

[17] Chao T, Chao H, Chen M, Greager JA, Walter RJ. Female sex hormones modulate the function of LPS-treated macrophages. Am J Reprod Immunol 2000; 44: 310-8. 
[18] Woodfork KA, Schuller KC, Huffman LJ. Cytokine and nitric oxide release by J774a.1 macrophages is not regulated by estradiol. Life Sci 2001; 69: 2287-94.

[19] Miller L, Alley EW, Murphy WJ, Russell SW, Hunt JS. Progesterone inhibits inducible nitric oxide synthase gene expression and nitric oxide production in murine macrophages. $\mathbf{J}$ Leukoc Biol 1996; 59: 442-50.

[20] Robert R, Spitzer JA. Effects of female hormones $17 \beta$-estradiol and progesterone) on nitric oxide production by alveolar macrophages in rats. Nitric Oxide 1997; 1: 453-62.

[21] Jones LA, Anthony JP, Henriquez FL, et al. Toll-like receptor-4mediated macrophage activation is differentially regulated by progesterone via the glucocorticoid and progesterone receptors. Immunology 2008; 125: 59-69.

[22] Kämmerer U, Eggert AO, Kapp M, et al. Unique appearance of proliferating antigen-presenting cells expressing DC-SIGN (CD209) in the decidua of early human pregnancy. Am J Pathol 2003; 162: 887-96.

[23] Kämmerer U, Schoppet M, McLellan AD, et al. Human decidua contains potent immunostimulatory $\mathrm{CD} 83+$ dendritic cells. Am J Pathol 2000; 157: 159-69.

[24] Ivanova E, Kyurkchiev D, Altankova I, Dimitrov J, Binakova E, Kyurkchiev S. CD83+ Monocyte-derived dendritic cells are present in human deciduas and progesterone induces their differentiation in vitro. Am J Reprod Immunol 2005; 53: 199-205.

[25] Juretic K, Strbo N, Crncic TB, Laskarin G, Rukavina D. An insight into the dendritic cells at the maternal-fetal interface. AJRI 2004; 52: $350-5$.

[26] Kangas L, Nieminen AL, Cantell K. Additive and synergistic effects of a novel antiestrogen, toremifene ( $\mathrm{Fc}-1157 \mathrm{a})$, and human interferons on estrogen responsive MCF-7 cells in vitro. Med Biol 1985; 63: 187-90.

[27] Paavonen T, Andersson LC. The oestrogen antagonists, tamoxifen and Fc-1157a, display oestrogen like effects on human lymphocyte functions in vitro. Clin Exp Immunol 1985; 61: 467-74.

[28] Paharka-Vatchkova V, Maldonado R, Kovats S. Estrogen preferentially promotes the differentiation of $\mathrm{CD} 11 \mathrm{c}+\mathrm{CD} 11 \mathrm{~b}^{\text {intermediate }}$ dendritic cells from bone marrow precursors. J Immunol 2004; 172 : 1426-36.

[29] Douin-Echinard V, Laffont S, Seillet C, et al. Estrogen receptor alpha, but not beta, is required for optimal dendritic cell differentiation and CD40-induced cytokine production. J Immunol 2008; 180: 3661-9.

[30] Beagley KW, Gockel CM. Regulation of innate and adaptive immunity by the female sex hormones oestradiol and progesterone. FEMS Immunol Med Microbiol 2003; 38: 13-22.

[31] Huck B, Steck T, Habersack M, Dietl J, Kämmerer U. Pregnancy associated hormones modulate the cytokine production but not the phenotype of PBMC-derived human dendritic cells. Eur J Obstet Gynecol 2005; 122: 85-94.

[32] Yang L, Liang J, Yao G, Chen P, Hou Y. 17ß-estradiol regulates the numbers, endocytosis, stimulative capacity and IL-10 secretion of mouse spleen dendritic cells. Toxicol Lett 2005; 155: 239-46.

[33] Yang L, Hu Y, Hou Y. Effects of $17^{\mathrm{b}}$-estradiol on the maturation, nuclear factor kappa B p65 and functions of murine spleen CD11cpositive dendritic cells. Mol Immunol 2006; 43: 357-66.

[34] Bengtsson AK, Ryan EJ, Giordano D, Magaletti DM, Clark EA. 17ß-estradiol (E2) modulates cytokine and chemokine expression in human monocyte-derived dendritic cells. Blood 2004; 104: 1404-10.

[35] Ashkar AA, Croy BA. Interferon- $\gamma$ contributes to the normalcy of murine pregnancy. Biol Reprod 1999; 61: 493-502.

[36] Croy BA, Ashkar AA, Minhas K, Greenwood JD. Can murine uterine natural killer cells give insights into the pathogenesis of preeclampsia? J Soc Gynecol Invest 2000; 7: 12-20.

[37] Ashkar AA, Di Santo JP, Croy BA. Interferon $\gamma$ contributes to initiation of uterine vascular modification, decidual integrity, and uterine natural killer cell maturation during normal murine pregnancy. J Exp Med 2000; 192: 259-69.

[38] Redline RW. Role of uterine natural killer cells and interferon $\gamma$ in placental development. J Exp Med 2000; 192: F1-F4.

[39] Miller JS. The biology of natural killer cells in cancer, infection and pregnancy. Exp Hematol 2001; 29: 1157-68.

[40] Croy BA, van den Heuvel MJ, Borzychowski AM, Tayade C. Uterine natural killer cells: a specialised differentiation regulated by ovarian hormones. Immunol Rev 2006; 214: 161-85.
[41] Higuma-Myojo S, Sasaki Y, Miyazaki S, et al. Cytokine profile of natural killer cells in early human pregnancy. AJRI 2005; 54: 21-9.

[42] Dorling A, Monk NJ, Lechler RI. HLA-G inhibits the transendothelial migration of human NK cells. Eur J Immunol 2000; 30: 586-93.

[43] Souza SS, Castro FA, Mendonça HC, et al. Influence of menstrual cycle on NK activity. J Reprod Immunol 2001; 50: 151-9.

[44] Szekeres-Bartho J, Faust Z, Varga P. The expression of a progesterone-induced immunomodulatory protein in pregnancy lymphocytes. Am J Reprod Immunol 1995; 34: 342-8.

[45] Szekeres-Bartho J, Par G, Dombay GY, Smart YC, Volgyi Z. The antiabortive effect of progesterone-induced blocking factor in mice is manifested by modulating NK activity. Cell Immunol 1997; 177: 194-9.

[46] Laskarin G, Tokmadzic VS, Strbo N, et al. Progesterone induced Blocking Factor (PIBF) mediates progesterone induced suppression of decidual lymphocyte cytotoxocity. Am J Reprod Immunol 2002; 48: 201-9.

[47] Par G, Geli J, Kozma N, Varga P, Szekeres-Bartho J. Progesterone regulates IL-12 expression in pregnancy lymphocytes by inhibiting phospholipase A2. Am J Reprod Immunol 2003; 49: 1-5.

[48] de Man YA, Bakker-Jonges LE, Dufour-van den Goorbergh DB, et al. Women with rheumatoid arthritis negative for anti-CCP and rheumatoid factor are more likely to improve during pregnancy, whereas in autoantibody positive women autoantibody levels are not influenced by pregnancy. Ann Rheum Dis 2009 [Epub ahead of print] Available from: http:// ard.bmj.com/cgi/rapidpdf/ard.2008. 104331v1

[49] Doria A, Iaccarino L, Arienti S, et al. Th2 immune deviation induced by pregnancy: the two faces of autoimmune rheumatic disease. Reprod Toxicol 2006; 22: 234-41.

[50] Lin H, Mosmann TR, Giobert L, Tuntipopipat S, Wegmann TG. Synthesis of $\mathrm{T}$ helper 2-type cytokines at the maternal-fetal interface. J Immunol 1993; 151: 4562-73.

[51] Miyaura H, Iwata M. Direct and indirect inhibition of Th1 development by progesterone and glucocorticoids. J Immunol 2002; 168: 1087-94.

[52] Szekeres-Bartho J, Wegmann TG. A progesterone-dependent immunomodulatory protein alters the Th1/Th2 balance. J Reprod Immunol 1996; 31: 81-95.

[53] Szereday L, Varga P, Szekeres-Bartho J. Cytokine production by lymphocytes in pregnancy. Am J Reprod Immunol 1997; 38: 41822.

[54] Kozma N, Halasz M, Polgar B, et al. Progesterone-induced blocking factor activates STAT6 via binding to a novel IL-4 receptor. J Immunol 2006; 176: 819-26.

[55] Kozma N, Halasz M, Palkovics T, Szekeres-Bartho J. The progesterone-induced blocking factor modulates the balance of PKC and intracellular Ca++. Am J Reprod Immunol 2006; 55: 1229.

[56] Pernis AB. Estrogen and CD4+ T cells. Curr Opin Rheumatol 2007; 19: 414-20.

[57] Klein SL. Hormones and mating system affect sex and species differences in immune function among vertebrates. Behav Proc 2000; 51: 149-66.

[58] Fox HS, Bond BL, Parslow TG. Estrogen regulates the IFN- $\gamma$ promoter. J Immunol 1991; 146: 4362-7.

[59] Maret A, Coudert JD, Garidou L, et al. Estradiol enhances primary antigen-specific CD4 $\mathrm{T}$ cell responses and Th1 development in vivo: essential role of estrogen receptor alpha expression in hematopoeitic cells. Eur J Immunol 2003; 33: 512-21.

[60] Tibbetts TA, DeMayo F, Rich S, Conneely OM, O’Malley BW. Progesterone receptors in the thymus are required for thymic involution during pregnancy and for normal fertility. Proc Natl Acad Sci USA 1999; 96: 12021-6.

[61] Rijhsinghani AG, Thompson K, Bhatia SK, Waldschmidt TJ. Estrogen blocks early $\mathrm{T}$ cell development in the thymus. Am J Reprod Immunol 1996; 36: 269-77.

[62] Saito S, Sasaki Y, Sakai M. $\mathrm{CD}^{+} \mathrm{CD} 25^{\text {high }}$ regulatory T cells in human pregnancy. J Reprod Immunol 2005; 65: 111-20.

[63] Zenclussen AC. CD4+CD25+ T regulatory cells in murine pregnancy. J Reprod Immunol 2005; 65: 101-10.

[64] Hori S, Nomura T, Sakagucji S. Control of regulatory $T$ cell development by the transcription factor Foxp3. Science 2003; 299: 1057-61. 
[65] Fontenot JD, Gavin MA, Rudensky AY. Foxp3 programs the development and function of CD4+CD25+ regulatory $\mathrm{T}$ cells. Nat Immunol 2003; 4: 330-6.

[66] Somerset DA, Zheng Y, Kilby MD, Sansom DM, Drayson MT. Normal human pregnancy is associated with an elevation in the immune suppressive $\mathrm{CD} 25^{+} \mathrm{CD} 4^{+}$regulatory $\mathrm{T}$-cell subset. Immunol 2004; 112: 38-43.

[67] Sasaki Y, Sakai M, Miyazaki S, Higuma S, Shiozaki A, Saito S. Decidual and peripheral blood CD4+CD25+ regulatory $\mathrm{T}$ cells in early pregnancy subjects and spontaneous abortion cases. Mol Hum Reprod 2004; 10: 347-53.

[68] Aluvihare VR, Kallikourdis M, Betz AG. Regulatory T cells mediate maternal tolerance to the fetus. Nat Immunol 2004; 5: 26671.

[69] Zhao J, Zeng Y, Liu Y. Fetal alloantigen is responsible for the expansion of the $\mathrm{CD} 4+\mathrm{CD} 25+$ regulatory $\mathrm{T}$ cell pool during pregnancy. J Reprod Immunol 2007; 75: 71-81.

[70] Munn DH, Shafizadeh E, Attwood JT, Bondarev I, Pashine A, Mellor AL. Inhibition of $\mathrm{T}$ cell proliferation by macrophage tryptophan metabolism. J Exp Med 1999; 189: 1363-72.

[71] Hwu P, Du MX, Lapointe R, Do M, Taylor MW, Young H. Indoleamine 2, 3-dioxygenase production by human dendritic cells results in the inhibition of $\mathrm{T}$ cell proliferation. J Immunol 2000; 164: 3596-9.

[72] Munn DH, Zhou M, Attwood JT, et al. Prevention of allogeneic fetal rejection by tryptophan catabolism. Science 1998; 281: 11913.

[73] Mellor AL, Munn DH. Tryptophan catabolism and T cell tolerance: immunosuppression by starvation? Immunol Today 1999; 20: 46973.

[74] Grohmann U, Fallerino F, Puccetti P. Tolerance, DCs and tryptophan: much ado about IDO. Trends Immunol 2003; 24: 2428 .

[75] Miwa N, Hayakawa S, Miyazaki S, et al. IDO expression on decidual and peripheral blood dendritic cells and monocytes/macrophages after treatment with CTLA-4 or interferon- $\gamma$ increase in normal pregnancy but decrease in spontaneous abortion. Mol Hum Reprod 2005; 11: 865-70.

[76] Polanczyk MJ, Hopke C, Huan J, Vandenbark AA, Offner H. Enhanced Foxp3 expression and treg cell function in pregnant and estrogen-treated mice. J Neuroimmunol 2005; 170: 85-92.

[77] Prieto GA, Rosenstein Y. Oestradiol potentiates the suppressive function of human $\mathrm{CD} 4+\mathrm{CD} 25+$ regulatory $\mathrm{T}$ cells by promoting their proliferation. Immunol 2006; 118: 58-65.

[78] Tai $\mathrm{P}$, Wang $\mathrm{J}$, Jin $\mathrm{H}$, et al. Induction of regulatory $\mathrm{T}$ cells by physiological level estrogen. J Cell Physiol 2008; 214: 456-64.

[79] Medina KL, Strasser A, Kincade PW. Estrogen influences the differentiation, proliferation, and survival of early B-lineage precursors. Blood 2000; 95: 2059-67.

[80] Medina KL, Kincade PW. Pregnancy-related steroids are potential negative regulators of B lymphopoiesis. Proc Natl Acad Sci USA 1994; 91: 5382-6.

[81] Caucheteux SM, Gendron MC, Kanellopoulos-Langevin C. Pregnancy-induced alterations of B cell maturation and survival are differentially affected by Fas and Bcl-2, independently of BcR expression. Int Immunol 2005; 17: 55-63.

[82] Yin P, Lin Z, Cheng YH, et al. Progesterone receptor regulates $\mathrm{Bcl}-2$ gene expression through direct binding to its promoter region in uterine myeloma cells. J Clin Endocrinol 2007; 92: 4459-66.

[83] Labeta MO, Margni RA, Leoni J, Binaghi RA. Structure of asymmetric non-precipitating antibody: presence of a carbohydrate residue in only one Fab region of the molecule. Immunol 1986; 57 : 311-7.

[84] Malan Borel I, Gentile T, Angelucci J, et al. IgG asymmetric molecules with antipaternal activity isolated from sera and placenta of pregnant human. J Reprod Immunol 1991; 20: 129-40.

[85] Keleman K, Bognar I, Paal M, Szekeres-Bartho J. A Progesteroneinduced protein increases the synthesis of asymmetric antibodies. Cell Immunol 1996; 167: 129-34.

[86] Zenclussen AC, Gentile T, Kortebani G, Mazzolli A, Margni R. Asymmetric antibodies and pregnancy. Am J Reprod Immunol 2001; 45: 289-94.

[87] Gutierrez G, Gentile T, Miranda S, Margni RA. Asymmetric antibodies: a protective arm in pregnancy. Chem Immunol Allergy 2005; 89: 158-68.
[88] Acconcia F, Kumar R. Signaling regulation of genomic and nongenomic functions of estrogen receptors. Cancer Lett 2006; 238: $1-14$.

[89] Zhang D, Trudeau VL. Integration of membrane and nuclear estrogen receptor signalling. Comp Biochem Physiol 2006; 144: 306-15.

[90] Matthews J, Gustafsson JA. Estrogen signaling: a subtle balance between ER- $\alpha$ and ER- $\beta$. Mol Interv 2003; 3: 281-92.

[91] Pappas TC, Gametchu B, Watson CS. Membrane estrogen receptors identified by multiple antibody labelling and impededligand binding. FASEB J 1995; 9: 404-10.

[92] Campbell CH, Bulayeva N, Brown DB, Gametchu B, Watson CS. Regulation of the membrane estrogen receptor- $\alpha$ : role of cell density, serum, cell passage number, and estradiol. FASEB J 2002; 16: 1917-27.

[93] Phiel KL, Henderson RA, Adelman SJ, Elloso MM. Differential estrogen receptor gene expression in human peripheral blood mononuclear cell populations. Immunol Lett 2005; 97: 107-13.

[94] Benten WPM, Lieberherr M, Gise G, Wunderlich F. Estradiol binding to cell surface raises cytosolic free calcium in $\mathrm{T}$ cells. FEBS Lett 1998; 422: 349-53.

[95] Benten WPM, Stephan C, Wunderlich F. B cells express intracellular but not surface receptors for testosterone and estradiol. Steroids 2002; 67: 647-54

[96] Cutolo M, Accardo S, Villaggio B, et al. Androgen and estrogen receptors are present in primary cultures of human synovial macrophages. J Clin Endocrinol Metab 1996; 81: 820-7.

[97] Khan KN, Masuzaki H, Fujishita A, et al. Estrogen and progesterone receptor expression in macrophages and regulation of hepatocyte growth factor by ovarian steroids in women with endometriosis. Hum Reprod 2005; 20: 2004-13.

[98] Kontula K, Paavonen T, Luukkainen T, Andersson LC. Binding of progestins to the glucocorticoid receptor. Biochem Pharmcol 1983; 32: 1511-8.

[99] Wei LL, Horwitz KB. The structure of progesterone receptors. Steroids 1985; 46: 677-95.

[100] Tsai MJ, O’Malley BW. Molecular mechanisms of action of steroid/thyroid receptor superfamily members. Annu Rev Biochem 1994; 63: 451-86.

[101] Jeltsch JM, Turcotte B, Garnier JM, et al. Characterisation of multiple mRNAs originating from the chicken progesterone receptor gene. Evidence for a specific transcript encoding form A. J Biol Chem 1990; 265: 3967-74.

[102] Kastner P, Krust A, Turcotte B, et al. Two distinct estrogenregulated promoters generate transcripts encoding the two functionally different human progesterone receptor forms A and $\mathrm{B}$. EMBO J 1990; 9: 1603-14.

[103] Giangrande PH, McDonnell DP. The A and B isoforms of the human progesterone receptor: two functionally different transcription factors encoded by a single gene. Recent Prog Horm Res 1999; 54: 291-313.

[104] Uotinen N, Puustinen R, Pasanen S, et al. Distribution of progesterone receptor in female mouse tissues. Gen Comp Endocrinol 1999; 115: 428-41.

[105] Flötotto $\mathrm{T}$, Niederacher $\mathrm{D}$, Hohmann $\mathrm{T}$, et al. Molecular mechanism of estrogen receptor (ER) $\alpha$-specific, estradioldependent expression of the progesterone receptor (PR)B-isoform. J Steroid Biochem Mol Biol 2004; 88: 131-42.

[106] Leonhardt SA, Boonyaratanakornkit V, Edwards DP. Progesterone receptor transcription and non-transcription signalling mechanisms. Steroids 2003; 68: 761-70.

[107] Fernandes MS, Brosens JJ, Gellersen B. Honey, we need to talk about the membrane progestin receptors. Steroids 2008; 73: 942-52

[108] King A, Gardner L, Loke YW. Evaluation of oestrogen and progesterone receptors expression in uterine mucosal lymphocytes. Hum Reprod 1996; 11: 1079-82.

[109] Arruvito L, Giulianelli S, Flores AC, et al. NK cells expressing a progesterone receptor are susceptible to progesterone-induced apoptosis. J Immunol 2008; 180: 5746-53.

[110] Dosiou C, Hamilton AE, Pang Y, et al. Expression of membrane progesterone receptors on human $\mathrm{T}$ lymphocytes and Jurkat cells and activation of G-proteins by progesterone. J Endocrinol 2008 ; 196: 67-77.

[111] Laurberg P, Bournaud C, Karmisholt J, Orgiazzi J. Management of Graves' hyperthyroidism in pregnancy: focus on both maternal and 
foetal thyroid function, and caution against surgical thyroidectomy in pregnancy. Eur J Endocrinol 2009; 160: 1-8.

[112] Haddow JE, Palomaki GE, Allan WC, et al. Maternal thyroid deficiency during pregnancy and subsequent neuropsychological development of the child. N Engl J Med 1999; 341: 549-55.

[113] Amino N, Tada H, Hidaka Y. Autoimmune thyroid disease and pregnancy. J Endocrinol Invest 1996; 19: 59-70.

[114] Azar ST, Tamim H, Beyhum HN, Habbal MZ, Almawi WY. Type I (insulin-dependent) diabetes is a Th1- and Th2-mediated autoimmune disease. Clin Diagn Lab Immunol 1999; 6: 306-10.

[115] Alstead EM, Nelson-Piercy C. Inflammatory bowel disease in pregnancy. Gut 2003; 52: 1591-61.

[116] Khosla R, Willoughby CP, Jewell DP. Crohn's disease and pregnancy. Gut 1984; 25: 52-6.

[117] Rogers RG, Katz VL. Course of Crohn's disease during pregnancy and its effect on pregnancy outcome: a retrospective review. Am J Perinatol 1995; 12: 262-4.

[118] Czymek R, Limmer S, Kleemann M, et al. Crohn's disease-a chameleon during pregnancy. Langenbecks Arch Surg 2009; 394: 517-27.

[119] Bortoli A, Saibeni S, Tatarella M, et al. The Study Group for Inflammatory Bowel Diseases GSMII. Pregnancy before and after the diagnosis of inflammatory bowel diseases: retrospective casecontrol study. J Gastroenterol Hepatol 2007; 22: 542-9.

[120] Scher MS. Maternal ulcerative colitis and fetal brain injury: longterm neurologic outcome. J Child Neurol 2007; 22: 1293-6.

[121] Wagner S, Craici I, Reed D, et al. Maternal and foetal outcomes in pregnant patients with active lupus nephritis. Lupus 2009; 18: 3427.

[122] Ostensen M. Sex hormones and pregnancy in rheumatoid arthritis and systemic lupus erythematosus. Ann N Y Acad Sci 1999; 876: 131-43.

[123] Khamashta MA, Ruiz-Irastorza G, Hughes GR. Systemic lupus erythematosus flares during pregnancy. Rheum Dis Clin North Am 1997; 23: 15-30.

[124] Buyon JP. Neonatal lupus. Curr Opin Rheumatol 1996; 8: 485-90.

[125] Lavalle C, Graef A, Baca V, et al. Prolactin and gonadal hormones: a key relationship that may have clinical, monitoring and therapeutic implications in systemic lupus erythematosus. Lupus 1993; 2(2): 71-5.

[126] Walker SE, McMurray RW, Houri JM, et al. Effects of prolactin in stimulating disease activity in systemic lupus erythematosus. Ann N Y Acad Sci 1998; 840: 762-72.

[127] Whyte A, Williams RO. Bromocriptine suppresses postpartum exacerbation of collagen-induced arthritis. Arthritis Rheum 1988; 31: 927-8

[128] Brennan P, Silman A. Breast-feeding and the onset of rheumatoid arthritis. Arthritis Rheum 1994; 37: 808-13.

[129] Lyde CB. Pregnancy in patients with Hansen disease. Arch Dermatol 1997; 133: 623-7.

[130] Duncan ME, Pearson JM, Rees RJ. The association of pregnancy and leprosy. II: pregnancy in dapsone-resistant leprosy. Lepr Rev 1981; 52: 263-70

[131] Gellin BG, Broome CV, Bibb WF, Weaver RE, Gaventa S, Mascola L. The epidemiology of listeriosis in the United States1986. Listeriosis Study Group. Am J Epidemiol 1991; 133: 392401.

[132] Palacios R, Senise J, Vaz M, et al. Short-term antiretroviral therapy to prevent mother-to-child transmission is safe and results in a sustained increase in CD4 $\mathrm{T}$ cell counts in HIV-1-infected mothers. HIV Med 2009; 10: 157-62.

[133] Neuzil KM, Reed GW, Mitchel EF, et al. Impact of influenza on acute cardiopulmonary hospitalizations in pregnant women. Am J Epidemiol 1998; 148: 1094-2.

[134] Atmar RL, Englund JA, Hammill H. Complications of measles during pregnancy. Clin Infect Dis 1992; 14: 217-26.

[135] Avelino MM, Campos D, Jr, do Carmo Barbosa de Parada J, de Castro AM. Pregnancy as a risk factor for acute toxoplasmosis seroconversion. Eur J Obstet Gynecol Reprod Biol 2003; 108: 1924.

[136] Menendez C. Malaria during pregnancy. Curr Mol Med 2006; 6: 269-73.

[137] Baeten JM, Lavreys L, Overbaugh J. The influence of hormonal contraceptive use on HIV-1 transmission and disease progression. Clin Infect Dis 2007; 45: 360-9.
[138] Leclerc PM, Dubois-Colas N, Garenne M. Hormonal contraception and HIV prevalence in four African countries. Contraception 2008; 77: 371-6.

[139] Poonia B, Wang X, Veazey RS. Distribution of simian immunodeficiency virus target cells in vaginal tissues of normal rhesus macaques: implications for virus transmission. J Reprod Immunol 2006; 72: 74-84.

[140] Yeaman GR, Howell AL, Weldon S, et al. Human immunodeficiency virus receptor and coreceptor expression on human uterine epithelial cells: regulation of expression during the menstrual cycle and implications for human immunodeficiency virus infection. Immunology 2003; 109: 137-46.

[141] Harper SA, Fukuda K, Uyeki TM, et al. Centers for Disease Control and Prevention (CDC) Advisory Committee on Immunization Practices (ACIP). Prevention and control of influenza: recommendations of the Advisory Committee on Immunization Practices (ACIP). MMWR Recomm Rep 2004; 53: 1-40. Erratum in: MMWR Recomm Rep 2004; 53: 743. Update in: MMWR Recomm Rep 2005; 54: 1-40.

[142] Roberts CW, Cruickshank SM, Alexander J. Sex-determined resistance to Toxoplasma gondii is associated with temporal differences in cytokine production. Infect Immun 1995; 63: 2549. 55 .

[143] Menzies FM, Henriquez FL, Roberts CW. Immunological control of congenital toxoplasmosis in the murine model. Immunol Lett 2008; 115: 83-9.

[144] Sher A, Oswald IP, Hieny S, Gazzinelli RT. Toxoplasma gondii induces a $\mathrm{T}$-independent IFN- $\gamma$ response in natural killer cells that requires both adherent accessory cells and tumor necrosis factor- $\alpha$. J Immunol 1993; 150: 3982-9.

[145] Hunter CA, Subauste CS, Van Cleave VH, Remington JS. Production of gamma interferon by natural killer cells from Toxoplasma gondii-infected SCID mice: regulation by interleukin10 , interleukin-12, and tumor necrosis factor alpha. Infect Immun 1994; 62: 2818-24

[146] Abou-Bacar A, Pfaff AW, Georges S, et al. Role of NK cells and gamma interferon in transplacental passage of Toxoplasma gondii in a mouse model of primary infection. Infect Immun 2004; 72 $1397-401$.

[147] Abou-Bacar A, Pfaff AW, Letscher-Bru V, et al. Role of gamma interferon and $\mathrm{T}$ cells in congenital Toxoplasma transmission. Parasite Immunol 2004; 26: 315-8.

[148] Shiono Y, Mun HS, Nakazaki Y, et al. Maternal-fetal transmission of Toxoplasma gondii in interferon- $\gamma$ deficient mice. Parasitol Int 2007; 56: 141-8.

[149] Desai M, Kuil FO, Nosten F, et al. Epidemiology and burden of malaria in pregnancy. Lancet Infect Dis 2007; 7: 93-104.

[150] Fried M, Muga RO, Misore AO, Duffy PE. Malaria elicits type I cytokines in the human placenta: IFN-gamma and TNF-alpha associated with pregnancy outcomes. J Immunol 1998; 160: 2523 30 .

[151] Schofield L, Grau GE Immunological processes in malaria pathogenesis. Nat Rev Immunol 2005; 5: 722-35.

[152] Klein PW, Easterbrook JD, Lalime EN, Klein SL. Estrogen and progesterone affect responses to malaria infection in female C57BL/6 mice. Gend Med 2008; 5: 423-33.

[153] Bouyou-Akotet MK, Adegnika AA, Agnandji ST, et al. Cortisol and susceptibility to malaria during pregnancy. Microb Infect 2005 7: 1217-23

[154] Krishnan L, Guilbert LJ, Wegmann TG, Belosevic M, Mosmann TR. T helper 1 response against Leishmania major in pregnant C57BL/6 mice increases implantation failure and fetal resorptions. J Immunol 1996; 156: 653-62.

[155] Krishnan L, Guilbert LJ, Russell AS, Wegmann TG, Mosmann TR, Belosevic M. Pregnancy impairs resistance of C57BL/6 mice to Leishmania major infection and causes decreased antigen-specific IFN-gamma response and increased production of $\mathrm{T}$ helper 2 cytokines. J Immunol 1996; 156: 644-52.

[156] Baszler TV, Long MT, McElwain TF, Mathison BA. Interferongamma and interleukin-12 mediate protection to acute Neospora caninum infection in BALB/c mice. Int J Parasitol 1999; 29: 163546.

[157] Quinn HE, Miller CMD, Ellis JT. The cell-mediated immune response to Neospora caninum during pregnancy in the mouse is associated with a bias towards production of interleukin-4. Int $J$ Parasitol 2004; 34: 723-32. 
[158] Kano R, Masukata Y, Omata Y, Kobayashi Y, Maeda R, Saito A. Relationship between type1/type2 immune responses and occurrence of vertical transmission in BALB/c mice infected with Neospora caninum. Vet Parasitol 2005; 129: 159-64.

[159] Maley SW, Buxton D, Macaldowie CN, et al. Characterisation of the immune response in the placenta of cattle experimentally infected with Neospora caninum in early gestation. J Comp Pathol 2006; 135: 130-41.

[160] Klevar S, Kulberg S, Boysen P, et al. Natural killer cells act as early responders in an experimental infection with Neospora caninum in calves. Int J Parsitol 2007; 37: 329-39.

[161] Moorman AM, Sullivan AD, Rochford RA, et al. Malaria and pregnancy: placental cytokine expression and its relationship to intrauterine growth retardation. J Infect Dis 1999; 180: 1987-93.

[162] Beeson JG, Duffy PE. The immunology and pathogenesis of malaria during pregnancy. Curr Top Microbiol Immunol 2005; 297: $187-227$.
[163] Torina A, Caracappa S, Barera A, et al. Toxocara canis infection induces antigen-specific IL-10 and IFN $\gamma$ production in pregnant dogs and their puppies. Vet Immunol Immunopathol 2005; 108: 247-51.

[164] Reierova K, Tomasovicova O, Dubinsky P. Influence of maternal infection on offspring immune response in murine larval toxocariasis. Parasite Immunol 2003; 25: 361-8.

[165] Hermann E, Truyens C, Alonso-Vega C, et al. Congenital transmission of Trypanosoma cruzi is associated with maternal enhanced parasitaemia and decreased production of interferon- $\gamma$ in response to parasite antigens. J Infect Dis 2004; 189: 1274-81.

[166] Mjihdi A, Lambot MA, Stewart IJ, et al. Acute Trypanosoma cruzi infection in mouse induces infertility of placental parasite invasion and ischemic necrosis associated with massive fetal loss. Am J Pathol 2002; 161: 673-80.

[167] Prigione I, Chiesa S, Taverna $\mathrm{P}$, et al. T cell mediated immune responses to Toxoplasma gondii in pregnant women with primary toxoplasmosis. Microbes Infect 2006; 8: 552-60.

(C) Menzies and Henriquez; Licensee Bentham Open.

This is an open access article licensed under the terms of the Creative Commons Attribution Non-Commercial License (http://creativecommons.org/licenses/by$\mathrm{nc} / 3.0 /$ ) which permits unrestricted, non-commercial use, distribution and reproduction in any medium, provided the work is properly cited. 